\title{
A Business Model in Spa Tourism Enterprises: Case Study from Poland
}

\author{
Adam R. Szromek*(i) and Mateusz Naramski (iD) \\ Department of Organization and Management, Institute of Economy and Informatics, Silesian University \\ of Technology, Akademicka 2A, 44-100 Gliwice, Poland; mateusz.naramski@polsl.pl \\ * Correspondence: innowator@o2.pl; Tel.: +48-32-277-7336
}

Received: 25 March 2019; Accepted: 17 May 2019; Published: 21 May 2019

\begin{abstract}
This article expands on knowledge about modeling tourism business. The basic scientific problem of the conducted research was the need to modernize the way of doing business in spa tourism enterprises by popularizing the business model and to provide an indication of the elements of the business model that should be grounded in the principles of sustainable spa development. The aim of the article is to present the results of our own research carried out in Polish spa enterprises in 2018. The key scientific issue was to examine the range of use of the business model templates in the management of tourism-treatment activities carried out in spas. Discussing the research results was preceded by a review of the literature on business models and the characteristics of activities carried out by spa tourism enterprises. The conducted research used qualitative methods, especially in-depth interviews, conducted with managers of the largest enterprises of spa tourism in Poland. Quantitative research was also conducted to examine the needs of tourists and patients. Our own scientific research has shown that spa enterprises in Poland very rarely and only within the scope limited to some elements of their activity, use the business model, and are not always aware of the wide range of its applications. As a result of the applications received, a business model dedicated to spa enterprises was developed. The article refers to the overtourism phenomenon in spas and indicates the need to put in business models, which are activities that protect spa areas against excessive pressure on tourism and the exploitation of natural resources.
\end{abstract}

Keywords: health resorts; management; Poland

\section{Introduction}

In Poland, there are 45 health resorts, meaning areas of confirmed therapeutic properties of the climate that may be a remedy to limit the negative influence of harmful phenomena on society. It seems that health tourism and especially spa tourism can limit both the negative effects of pollution by engaging in tourism in natural areas and at the same time meet the demanding needs of the aging society to maintain good health for as long as possible [1].

The hitherto social role of spas, which perform mainly social functions in the field of health care and health prevention, is undergoing significant changes, caused by several significant events. Although the changes in the market of spa treatment services are usually evolutionary in nature, as they have been occurring since the beginning of the 1990s, there is still a clear discrepancy between the potential of Polish health resort enterprises and its use, as well as between the needs reported by the market and the offers of most tourist and healing establishments. An additional feature of the noticeable changes is the ambiguous perspective of conducting the spa facility, because while some facilities continue to operate almost exclusively in pursuit of social objectives, others seem to direct the purposefulness of their operations almost exclusively towards economic effects, and far later towards social effects, for which health resort activities have been included in the health care system [2]. 
The progressing transformation of tourist and healing activities in the scope of broadly understood organizational and market processes reveals at the same time that the tools for operating this activity are outdated. The functioning of an enterprise deprived of reliable strategic tools in a turbulent environment is becoming more and more difficult, and the lack of response to the reported market needs may even lead to a crisis. It is necessary to offer managers modern management tools, covering the broadest possible scope of integration of elements of the conducted business activities, and at the same time, adjusting to the specificity of the market in which the enterprises managed by them operate $[3,4]$. The proposal formulated in the light of the presented needs is to use the concept of business models to develop a business model of a spa enterprise adapted to the existing conditions of tourist and healing activities.

The basic research problem discussed in this paper results from difficulties in developing a business model dedicated to health resort enterprises, as it requires both theoretical knowledge of the activities of health resort enterprises and available business modeling concepts, as well as empirical research on business practice concerning the elements of tourism and health resort activity and market expectations of the customers. The area of issues includes issues related to business models and the activities of spa enterprises. However, the latter issue requires the identification of two other areas of knowledge directly related to the tourist and healing activities. The first one is health tourism carried out in spas, while the second area of scientific knowledge which is closely related to health tourism, is therapeutic activity within the scope of spa treatment (conducted on the basis of medical specialization concerning balneology and physical medicine).

It is also worth noting the phenomenon of overtourism [5], which also applies to the spa areas. As literature shows, most often tourism concentrates on economic and social viability at the expense of environmental sustainable development. Some scientists are trying to develop environmental policy integration [6], but it is generally difficult to implement. The problem of overtourism in tourism destinations and spas was noticed in the 1980s in the concept of TALC (Tourism Area Life Cycle) put forward by R.W. Butler [7] and its modifications or development hypotheses [8]. The arduous impact of excessive tourist traffic in a health resort may deprive the area of its features that distinguish it among other tourist areas. However, the literature proves that other important factors affecting the load on the area are also the behavior of visitors, duration of stay, concentration of tourists, and the type of tourism $[9,10]$. Therefore, all business activities in this area should take into account not only the profits, but also the social role of spa enterprises and their sustainable development [11]. However, in order to find a balance between the expansion of business activities and its permissible interference in the spa area, activities aimed at sustainable development should be included in contemporary business models.

The existing research achievements in the field of business models in tourist and healing enterprises proves that this area is still unexplored, and few studies in this area concern only a fragmentary approach to the subject [12]. There are some works that address the characteristics of particular elements of the business model, rather than its complete form, as well as those that include business models developed for tourism activities in other areas, e.g., related to post-industrial cultural heritage tourism [13]. Researchers in the field of tourism economics generally focus their attention on individual elements of spa activity, e.g., on a health resort product, as a value proposition or on selected segments of customers, forgetting about the importance of other elements of the activities and about the mutual relations between these elements. Such a possibility is offered by business models, especially the model dedicated to spa enterprises.

In relation to the research problem identified above and the current state of knowledge in the subject under discussion, it is possible to identify a clear cognitive gap, which should be defined as a lack of knowledge on the applicability of business models and their elements in modern spa enterprises, as well as the possibility of a model approach to tourist and health resort activities conducted in health resorts using a business model dedicated to health resort enterprises. 
The cognitive purpose of the paper is to recognize the scope of applicability of the business model in spa enterprises, using Polish spa enterprises as an example. The implementation of the goal of the article will allow us to answer two questions-what is the range of applicability of business models in spa enterprises and what are the characteristics of elements of business models of spa enterprises? The identification of the research problem made it possible to define research questions and at the same time allowed us to organize the research process and direct its further preliminary stages towards determining its purpose. Knowing and understanding the mechanisms of conducting spa business, establishing what constitutes the components of the business model of spa enterprises, and consequently proposing a business model dedicated to health resort enterprises was a key vision for the implementation of the research works presented in the article.

\section{Literature Review}

Business models in the economic sense have been known in the literature only since the 1970s [14], when E. Konczal [15] added to business models a managerial value, clearly suggesting that they should not be perceived only as scientific or natural science tools. Since then, the models started to be associated with business, but their usage was not widespread. When looking at modern definitions of business models, one can notice that they are perceived though the discipline of a particular researcher. They can be perceived as a synthetic description of the business nature [16] or as a tool [17] describing the relations between the components that lead to the development and capturing of value by the organization [18].

The perspective of perceiving business models through description is confirmed by J. Magretta [16]. She considers the business models to be a story explaining how the enterprise works. More detailed definitions can be found in the perspective related to the tool character of the business model. D. Teece [17] perceives them as a tool describing the design or architecture of creation, supply or value-capturing mechanisms. He also notes that the core of a business model is defining the way in which the enterprise captures the value for the customers, entices them to pay for this value, and converts payables into profits. S. Prendeville and N. Bocken [19] perceive the business model similarly. They describe it as a conceptual tool describing the activities that refer to business transactions between customers, partners and suppliers and the organization and their participation in the development and capturing of value.

When paying attention to the tool character of the business models, it was emphasized that they are not only used to describe the business reality, but also-when effectively used-to shape this reality. For that purpose, it is important to indicate elements of that model and relations that occur between them. It was emphasized by M. Geissdoerfer et al. [20], who defined the business model as a simplified representation of organization elements, together with the interaction between these elements, to analyze, plan and communicate in the intricate organizational structure. A similar approach is presented by M. Johnson et al. [21], describing it as interrelated elements, that is, the proposal of value, profit formula, key processes, and resources that create and deliver the value.

T. Falencikowski [22] believes that a business model is a multi-component unit, developed and separated to present, in a simplified way, the manner of running a business, by describing the logic of value creation for the consumer and capturing its part by the enterprise. B. Rusu [23] also maintains the above assumption and understands the business model as a correlation system that enables the creation of value for customers based on enhanced planning of architecture of the designed system and correlated activities. A. Wiśniewski [24] presents a specific way of perceiving the revenue. He defines the business model by referring to the basic concepts and presents it as a description of construction, activity and correlations in a venture that generates profits.

C. Batistella et al. [18] have an interesting approach to this subject. They pay attention to the relations with other manager tools. They assume that the business model presents how the strategy is implemented by description of creation, supply and recording of economic, social or other values. The description of relations with other manager tools and manners of value creation and capturing can 
occur in two ways: with the use of description or graphics. It is emphasized by M. Al.-Debei et al. [25], who perceive business models as an abstract textual or graphic representation of interrelated structures of model architecture prepared by the organization and of all the products and services, that the organization has in offer and that are essential to achieve its aim.

B. Iwasieczko [26] defines a business model as a configuration of business elements established to create value for the customers and to be an element of effective competition. B. Nogalski [4] has similar views, while also paying attention to the resources being a key aspect of an organization. He described a business model as a characteristic of value for the customer, a set of basic resources, activities and relations with partners, the aim of which is to create this value and competitive advantage.

The issue of business models in tourism is rarely discussed in literature. In general, it is analyzed in a context of another major subject, such as knowledge and technology or in the scope of innovations. An example can be the work of J. Souto [27], who focuses on the research on the innovation in the scope of business modeling and implementation of innovations. It can also be noticed that much thought is devoted to knowledge as a strategic resource of innovative enterprises. The proper usage of knowledge enables one to design more attractive tourism experiences and more innovative marketing channels through which new recipients can be reached [28].

Some enterprises gain knowledge on their customers and their preferences by building relations with them. F. Mantaguti and E. Mingotto [29] when researching tourism enterprises in the small and medium enterprises sector, noticed that an important success factor is the common identification between the entrepreneur, staff and customers, especially with the use of electronic media.

Many tourism enterprises in their business models often assume new technologies to be indispensable elements to maintain competitiveness and profitability [30]. In that publication, the subject of creating value for the consumer of tourism services with the use of augmented reality was discussed. When researching the technology potential as a value proposal, the researchers noticed that there is significant support from the side of visitors and stakeholders. Among the advantages to which the researches paid attention was the increase of tourism attractiveness, revenues and competitiveness. Augmented reality is definitely an interesting proposal when diversifying the product of tourism enterprises. However, it is an additional element, supporting the basic product, just like other modern technologies.

An example of diversifying the offer is the use of a multimedia application to present tourist attractions. In their publication on innovative museums, C. Ciurea and F. G. Filip [31] indicate the advantages of such a solution. According to them, it can be a possibility to present the collections to which access is difficult (for example, delicate museum pieces). Moreover, they describe the possibility of using the tool by many entities, when in case a number of museums belong to a common network, virtual exhibitions can be opened, expanding the displayed heritage by adding pieces or collections belonging to other facilities.

Publications concerning the establishment or co-establishment of value for the customer, both in terms of sustainable tourism [28,32] and in creating value [33], are a valuable inspiration when creating innovative business models. An interesting discussion on business models in the tourism sector concerns the accommodation and catering services. M. Diaconu and A. Dutu [34] paid attention to the evolution of the hotel industry towards innovative business models. They emphasized that this results from the belief that the development of new technologies became a way to achieve success, as it offers the possibility to expand the distribution channels, reduces the time of reservation bookings, and creates a network of organizations engaged in maintaining the value chain.

Similar views are expressed by L. Knop and J. Brzóska [35], who in their characterization of a business model focus on the customers and what the enterprise can offer them. They describe the business model as configuration system of resources and activities (intercorrelated), covering among others the creation of values that on the one hand need to satisfy the needs of the customer and on the other hand need to be a source of revenue for the enterprise. J. Gordijn and H. Akkermans [36], when describing the enterprises of the energy sector, developed a sequence called "BusMod", being a 
gradual general methodological process of modeling and analyzing business activity. They identified six construction stages. In the proposed sequence, the authors underlined the value of the idea as a crucial stage being the beginning of business designing. It is the first step of business model creation in which a central axis is formulated with which the remaining components will be aligned. The value of the idea is to be a source of knowledge on the reasons why the customer will be likely to use the end product; therefore, next, it is proposed to create a list of business goals and their priorities. It makes it possible to adjust and select the technologies necessary to implement these goals. By implementing particular stages of the presented designing sequence, one can obtain a values model based on the available resources, key activities and business partners. Next, the prepared values model needs to be analyzed in terms of profitability. The procedure ends with preparing scenarios of business model development. It is an example of business modeling taking into account the linear character of the designing process.

H. Chesbrough [37] argues that innovation in business models has vital importance but at the same time, it is hard to achieve. The reason is, that even with help of tools like business maps, charts, or CANVAS are helpful to bring a change into a business model. However, the realization of that change is challenging, because when the model changes, the organizational processes has to change as well, and those are not mapped by such tools. Therefore, the curtailed tasks of introducing innovations into business models lays on internal leaders who can manage the change a deliver relay functioning innovative models.

Innovation in a business model should concentrate on the value proposition it includes, adopting it to the ever-changing market conditions and customer demands. One can say that the main purpose of a business model is to respond to the needs of clients, building all other elements around it. This finds reflection in the very definition of a business model used by D. Teece [38], who defines a business model as a description of a design of architecture of value creation, delivery and capture mechanisms. So, the main function of such a model is to recognize customers' needs and their ability to pay for fulfilling this need. It also defines the manner of how an enterprise responds to those needs by delivering value to the customers. In other words, a business model tells the company what the client wants, how they want it, what they are willing to pay for it, and how the enterprise should be organized to meet those needs as best as it can, getting paid well for doing so.

The same applies to business models in tourism; therefore, the key aspect to understanding their role in a tourist enterprise, it is crucial to examine the receiving side first: who are the clients, what is it that they want, and what makes the value of the delivered product for them.

In business models for tourism enterprises, the offer has to respond to the needs and preferences of tourists, so their perspective on the value proposition is highly important. This is especially significant in the case of spa facilities that mainly service domestic visitors. As S. Page [39] notices, domestic tourism is the dominant form of tourist activity in terms of traffic volume. So studying the local preferences and needs serves to improve the part of the tourist sector that has the biggest impact on all of the tourist traffic in the country. Findings from Central Europe confirm, that in the case of countries like Poland or Czech Republic, tourists prefer domestic products [40] and value them more over abroad alternatives. Therefore, it is much more suited to continuously update the state of knowledge about detailed tourist perceptions of a product, rather than using generalized data and observations about global trends; even if they are accurate, they may lack specific details. Moreover, while knowledge about international tourism is relatively broad and in center of researchers interest [41], domestic tourism gets oftentimes marginalized, staying unknown and rarely researched [42]. This is because international tourism is oftentimes perceived as having more economic importance in comparison to domestic tourism [43].

Even if the concept of business models has previously not been approached in spa tourism, or even other forms of tourism, i.e., heritage tourism (before the authors first researched on this matter [13]), value proposition has been studied in various forms of tourism, it was not examined from the business model's perspective most of the time. The vast majority of the research that unintendedly 
did that were the studies on tourist perception of a destination, or those where tourist satisfaction was measured and examined. One can name multiple examples of such an activity, like, for instance, the research on international tourists' perception of Kuala Lumpur by N.A. Ragavan, H. Subramonian and S.P. Sharif [44], where the authors conducted a survey in order to determine the impact on tourist perception such attributes like accommodation and food, attractions, climate, culture etc. have. A similar approach was taken by M. Kozak [45] when he studied tourist satisfaction among British and German visitors in Mallorca and Turkey. Again, the factors taken into consideration among others included: accommodation service, hospitality and customer care, facilities and activities, transport services, and pricing. J.S. Akama [46] tackled the issue of tourist satisfaction in Kenya's safaris by comparing visitors' perception grades with expectation grades that concerned various aspects of this kind of tourism (i.e., natural attractions, facilities-the looks and functionality of them, staff's attitude, and pricing). One can find similar approaches in recent works as well [47,48].

While results obtained using such methods can be compared within studies that approach similar forms of tourism (i.e., vacation tourism to marine locations, holidays in tourist resorts etc.), cross form comparisons might give false results. It is the very core of a touristic product that makes up the value for customers. Heritage tourists expect authentic culture to be in the center; spa clients seek health improvement in the first place; families taking a 2 week vacation in a beach resort are there for the sun, beach, entertainment and hotel living comfort etc. Therefore, this study being the first one that focuses on the issue of value proposal in spas not only fills a recognized research gap, but also might be used to perform such comparisons for other studies in this field.

\section{Method}

Research carried out in the field of a business model and its applicability in spa enterprises requires a step-by-step procedure. In the first stage of empirical research, qualitative research was carried out based on in-depth interviews conducted among managers of the largest spa enterprises in Poland. The research carried out at this stage made it possible to identify the scope of applicability of business models in spa enterprises.

The second stage of research concerns the task of getting to know and analyzing the preferences and expectations of tourists visiting Polish spas, as well as potential tourists in order to formulate the value proposition for the client. This stage of empirical research is aimed at getting to know the necessary activities aimed at identifying a potential additional segment of Polish spa clients and extending the scope of existing activities in the light of observed cultural and demographic changes.

In the research stage of spa enterprises, the study was attended to by managers of 17 entities which together provide 33\% of all health resort treatment services in Poland, operating in 95 facilities (sanatoriums and spa hospitals), which constitute $36 \%$ of all facilities in Poland. The research was carried out in 2018.

The companies analyzed were selected from the list of spa treatment establishments developed and made available by the Ministry of Health of the Republic of Poland. The choice was made based on the potential of the services provided-these were the largest spa enterprises in Poland in terms of annual visitor count and accommodation capacity. Some of those enterprises are spread across multiple health resorts in various towns. Such a choice of research subjects provided a good insight into the discussed industry and allowed to draw conclusions of enough significance to picture the current state of spas in Poland. The research questionnaire consisted of two parts. The first one included 18 questions characterizing the structure of the business model, enabling a description of each of the model's components. In the second part of the questionnaire, the subject of general information on the conducted activity and sources of its financing was taken (eight questions). Some of the questions concerned not only the indication of selected variants of the answer, but also their weighing. The responses helped to formulate a universal model of a spa enterprise business.

The methodological objective was also possible through empirical research and its subsequent use in the conceptual phase. The basis for the research and analysis was the most popular business 
model scheme CANVAS by A. Osterwalder and Y. Pigneur [49] because of its dual prominence; it is a tool, but also a concept that describes what a business model is, by breaking it down into nine key elements. Among them, we can distinguish: (1) customers' segment, being the axis of each business model; (2) proposals of values for selected customers' segments; (3) communication channels between the defined elements; (4) relations with customers; (5) revenue streams; (6) key resources, (7) key activities; (8) key partners; and (9) cost structure, meaning all the costs related to the execution of the defined business model. Nine of the mentioned elements are defined as the business model template. They compare the tool to a canvas which can be used to paint a picture of the existing or new business model. The utilitarian character of CANVAS makes it also a suited research tool, thanks to this clear division of a business model into elementary pieces. By studying each of them separately, it is possible to gather data that describes the whole picture of the business model in full detail, focusing on all nine aspects, oftentimes using different sources for fully understanding each of them. While asking the managers directly to describe their business model, the outcomes might be incomparable if even provided, given the low rate of familiarity with the business model concept among spa managers, and considering the vast selection of definitions describing business models.

According to the adopted research methodology, the implementation of the objectives of this work assumed the application of a step-by-step approach, in which the current state of the situation is first identified, concerning both the activities of spa enterprises, the scope of application of business models in health resort enterprises, and the characteristics of individual components (elements) of the business model. Due to the diversity of factors influencing health resort operations, it was also necessary to learn about the nature of organizational and social changes that affect the situation of the spa enterprises (Figure 1).

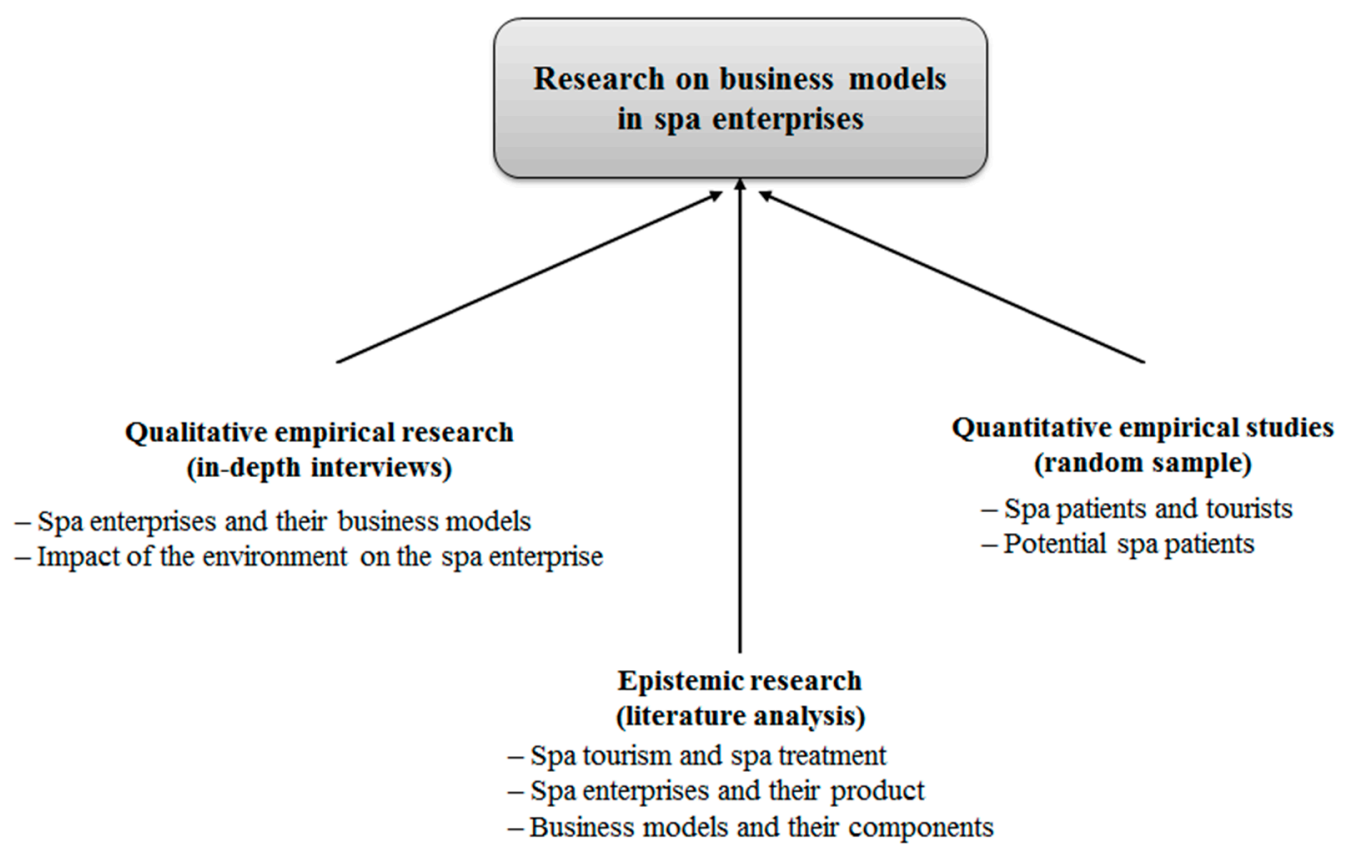

Figure 1. Research areas discussed in empirical and theoretical research. Source: Own study.

In terms of tasks, the first stage of the research consisted of in-depth interviews on the applicability of business models of selected spa enterprises, considering their forms, as well as the characterization of particular elements of the applied business strategy (in the absence of business models). In the second stage, the preferences of patients concerning the spa treatment services and the needs of potential patients were analyzed, which constituted the basis for a conclusion concerning the proposal of value for the spa customer, for it is a key element of each business model that shapes all its other elements. 
In the research of tourist expectations, a research survey was made available to determine their expectations regarding the offer of Polish health resorts, and at the same time, to develop a proposal of value for visitors. The study mainly concerned people who had already completed a spa treatment, but potential clients were excluded, and the research required reaching those people in their everyday life environment. The questionnaire contained 34 questions and was divided into three major parts. The first and last one included questions for all participants, while the second one contained two sets of questions-one for spa visitors and one for potential visitors. Answers that where given by the respondents in the first part decided what set of questions they should receive in the second part. This way, the conducted research allowed us to gather opinions of spa visitors, as well as get to know the expectations of potential clients. Clients who visited a spa in the last 10 years where asked about their experiences and needs, while the potential clients explained why they have not visited a spa so far and what their expectations are. The questionnaire was made available and disseminated on the Internet on social networks related to health resorts, and people interested in the subject were made available in the Internet community. Eight-hundred-and-ten people participated in the study. After the selection of the collected questionnaires for further research, 753 respondents were qualified, of which $63.5 \%$ (478 people) were patients of Polish health resorts (TS), i.e., people who had been in one of the Polish spas in the last 10 years. The second group of respondents ( 275 respondents) are people who have never been to Polish health resorts, and who at the same time express such a desire, having specific expectations (PT).

In the tourist group, 478 responses were obtained, which exceeded the minimum sample size estimated at 474 surveys (for the accepted level of maximum statistical error of the sample of $\pm 4.5 \%$ and the confidence level $p=0.95$ ). In the case of potential patients, the maximum statistical error of the sample is $\pm 6 \%$, with the assumed significance level of $\alpha=0.05$ (then the minimum size of the research sample is 267 respondents).

Statistical analysis of the collected data required the use of descriptive methods (arithmetic average supplemented by standard deviation) and intergroup comparisons (attribute significance index based on the structure index). In the case of normal distribution variables, the Student's $t$-test was used to compare two mean values in the independent groups tested, first determining the uniformity of variance (Fisher-Snedecor test) [50,51]. For a comparison of the two groups with non-normal distribution, the $\mathrm{U}$ (Mann-Whitney) test was used [52]. As a result, this stage of research allowed us to learn about the needs of both spa patients and potential patients, which at the same time made it possible to focus on developing a proposal of value consistent with the needs of the market. Then, it was also possible to integrate the structure of the obtained spa product into the business model.

In accordance with the adopted approach to research, the preliminary identification of the research problem led to a conclusion on the classification of the undertaken research. Therefore, it should be stressed that they were applied research in both descriptive and practical terms. However, using the physical criterion, the undertaken research was primarily of a qualitative nature, although quantitative research was also carried out in the dimension of creating a value proposition for the patient.

\section{Results}

The presented results are divided into two parts that correspond to the two different groups of research subjects. In the first subsection, findings from the literature review regarding business models are presented. Those are supplemented by the findings from in-depth interviews of spas' managers, giving an overall insight into all key elements of a business model used in a current spa enterprise. Because value proposition is the key component of every business model, and because it can be perceived from two perspectives, the company's and the customers point of view, the second subsection is dedicated to the standpoint of spa visitors. It contains findings obtained through the previously described questionnaire, regarding expectations and value for spa customers and potential customers. The results of both findings are used in the discussion section in order to get a comprehensive model of 
a spa enterprise business that meets both the issues of running a spa business from the enterprises stand point, as well as meeting the needs of clients in the form of expectations towards value proposition.

\subsection{The Structure and Chararcetistics of a Business Model in Modern Spas}

The exploration of the literature on the subject was conducted in the direction of the characteristics of the activities of spa enterprises. It includes social and economic factors (both historical and contemporary) that influence the current situation of the sector. The analysis of literature has also made it possible to identify historical changes in Polish spas and to cite selected concepts for the development of health resort areas.

The literature research undertaken allowed us to point out the key economic and social transformations (including cultural) affecting the current situation of the spa enterprises. It is possible to see three factors of influence. The transformation of health resort enterprises is conditioned by the market, product and ownership changes. They take:

- market character (through the marketization of spa services and the change of the existing therapeutic form of activity into tourist and healing activity, methods of financing, and scope of services for spa guests),

- product character (e.g., due to the fashion for a healthy lifestyle and the transformation of a traditional spa product, which allowed us to offer a mixed form of a spa product and openness to tourists), and

- ownership character (e.g., through privatization of state-owned spa enterprises, which changed the social perspective of conducting spa business into a perspective focused primarily on the economic result).

The in-depth interviews revealed that the actual knowledge of business models among managers of the studied companies is negligible and fragmentary, as it usually refers to their abstract understanding, but without text or graphic representation of the related architecture structures of the model or the proposed services. Only 5 managers among 17 surveyed spa establishments declared knowledge and use of the business model in running a spa activity. In every third establishment (29.4\%), there were studies concerning particular elements of the business activity, i.e., key activities, market segments, communication channels, and customer relations. None of the studied enterprises showed a compact characterization of the components of the company's business model or a formalized attempt to integrate all components of the business model based on the business model concepts known in the literature. The acquired information on the knowledge and applicability of business models in spa enterprises allowed us to confirm that the spa enterprises in Poland use the business model very rarely and only to the extent limited to certain elements of their activity, and not always with the awareness of the wide range of possibilities of its application. The use of the business model in the largest Polish spa companies is incidental and limited by the scope of selected elements of the business. In the vast majority of the studied enterprises, the issue of applying the business model in enterprise management was completely unknown.

The conducted empirical (qualitative) studies revealed that the activity of modern spa enterprises is focused primarily on achieving economic effects by increasing profit, the source of which is an increase of commercial stays in the total number of spa stays, and only then it is focused on the implementation of health functions within the health care system. This also allowed us to identify three key values determining the essence of the spa business. These were: the value for the spa patient, the value intercepted by the enterprise, and the social value, showing the importance of a health resort activity in the fulfillment of the health function of society.

The results of the research on the components of the business model are presented in Table 1, while below each of the elements of the business model obtained are discussed separately. 
Table 1. The structure of the business model of a health resort enterprise.

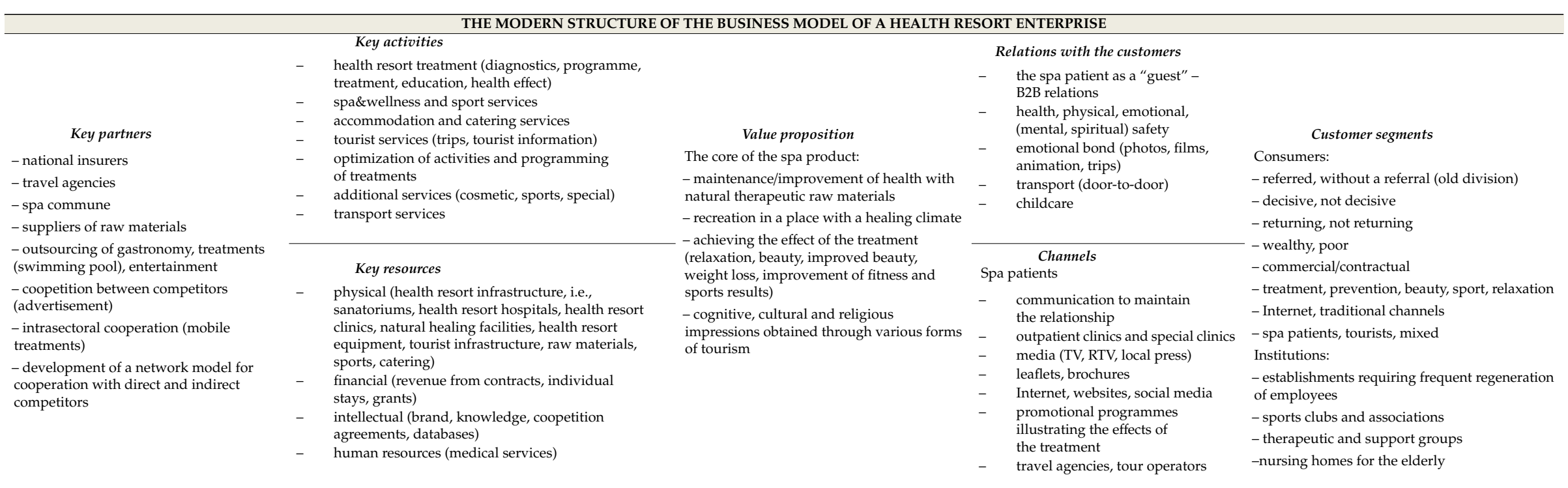

\section{Cost structure}

hotel and catering costs

costs of tretring

costs of maintenance of natural medicine infrastructure

costs of natural resources

costs of media consumption

ainment, education

costs of medical care

(1)
Revenue streams

Sources: contracts with insurers, individual and group patients, entrepreneurs, sports organizations.

spa treatment and its programme (treatments, diagnostics and medical care) and separation from harmful influence of civilization

satisfaction with accommodation, food and information

quality of the spa and wellness offer as well as sport and recreation

availability of tourist attraction

Price mechanisms:

- for individual and group customers (catalog price, price depending on product characteristics, price depending on market segment, price depending on

for contractual customers (negotiations, management of resources, price depending on the volume of transactions) 
According to the results of the research, the key partners of spa enterprises are entities with which cooperation provides the facility with offers of values to be intercepted, i.e., state health and social insurance companies, as they enable the spa enterprises to achieve the revenues from the execution of contracts. The second category is travel agencies, which allow patients who finance their own stay to get to know the offers of the facility. Other partners are the health resort communes, represented by the local government administrating the commune, as well as suppliers of natural resources, competitors with whom the facilities cooperate on a coopetition basis, and outsourcing companies.

An interesting feature of this element of the model is the noticeable need for coopetition with competitors from the same region, e.g., in order to reduce the costs of promoting the spa features of the region. Joint therapeutic programs based on intrasectoral cooperation are also important. It is, at the same time, an innovation that meets the needs of the spa patients who prefer to change the place of treatment within the same stimulus effect. An important element of this component is also the possibility of building cooperation networks between the spa competitors (both direct and indirect) within the scope of complementary and substitutable products.

Key activities directly related to the spa activity include accommodation services, health resort treatment services (natural therapies), as well as catering services and treatment programming, i.e., the establishment of a treatment plan. An important role is also played by such activities as assistance of a dietitian or psychologist, health resort clinic services, and health education classes.

The key activities should be complemented by services extending the spa treatment, such as tourist services and animation of leisure time. It is necessary to introduce methods to optimize accommodation (reducing hotel costs) and the implementation of therapeutic treatments (which should improve the consumer satisfaction). It is also necessary to extend the spa offer with spa \& wellness services, which so far have been provided by local entrepreneurs on a rather small scale.

An important activity should also be monitoring the load of the spa (spa park) with the intensity of tourist traffic and responding to exceeding the established limits. The city authorities may limit the possibility of increasing the number of beds in sanatoria and spa hotels. It is also necessary to monitor the drainage of the spa water deposits.

In the scope of key resources, the necessity for continuous education of the treatment personnel and creation of databases of existing and potential customers, which are worth reaching with the offer or recall the emotions that accompanied them during their previous stay, was noticed. According to the conducted research, the most valuable resources at the disposal of the spa facilities are the medical infrastructure and employees, as well as intellectual resources (conducted therapies). Elements of accommodation and catering facilities are also important resources. In the facilities where the activity was based on obtaining medicinal raw materials (mineral waters, salt water, salt, thermal waters, and therapeutic mud), raw materials were also a significant resource.

The spa managers declare that building positive relations with customers is based on activities focused on new and existing customers and on running loyalty programs. Currently, the development of relations with new customers is mainly performed through Internet tools, i.e., social networking sites and the so-called "open door", medical conferences, and direct offers addressed to organizations that may be interested in the facility's offer. Similarly, in the case of existing patients visiting the facility, the encouragement to develop a lasting relationship is usually an offer of cheaper stay (loyalty card, price discounts).

The method of establishing and developing customer relations depends on the segment of concerned customers. The segments of individual and business customers are the target groups in terms of building positive relations, because the actions taken towards them are intended to result in the return of the patient to the facility or to promote good reputation for the services provided there through word-of-mouth marketing. Contract patients do not choose the place of treatment themselves, which means that the relationship with them is not built or can be described as very limited. This is due to the lack of decision making by the patient about the place of treatment, because even if they chose a specific health resort, they cannot choose a spa enterprise in which they would like to stay. This seems 
to be a mistake, because the patient's willingness to return is not taken into account, even for a shorter period of time within the guest's own resources.

Building a lasting relationship with patients requires a change in the attitude of the spa's employees towards the persons undergoing the treatment. So far, the spa patients have been treated as kinds of medical patients, which raises a lot of controversies, especially when they come to the spa not only for health purposes. The attitude of the personnel should be oriented towards hospitality, and thus towards treating patients as guests (welcome and expected) and offering them a friendly atmosphere. It is also a solution, the effect of which may have an impact on the profitability of a spa facility.

An advantage of building relations can be the introduction of transport convenience "from door to door", i.e., offering the possibility of comfortable transport of the patient from the house door to the sanatorium door and return transport, or at least transport from and to the places of access to the means of transport. The necessity of this innovation is seen in the reduction of stress factors among spa patients, and at the same time, it increases the satisfaction of the whole treatment at low costs to themselves.

Significant changes also occur in the case of the served customers' segment. The managers of health resorts usually point to the segment of institutional (contractual) customers, the segment of individual (commercial) customers, and the segment of business customers. Some segments of customers already served will require additional benefits in order to bring the spa offer closer to a wider audience. These will be, for example, care services for underage children, so that their mothers can participate in the spa treatment without interruption.

It is possible to separate other sectors of spa customers. These may be tourists for whom the spa's activity has only cognitive and recreational, but not health significance. There is also growing importance of customers using SPA services as well as organized, employee and special groups with different service profiles. Re-segmentation of the market of spa service recipients requires rethinking a number of criteria that may have an important role in identifying key segments in the individual approach of spa facilities. An important issue is not only the method of financing the patient's stay, but also the awareness of the choice of place and time of stay in the spa, as well as the duration of the treatment. An important factor will also be the purpose of arrival, as well as the practice of returning to the same place or experience in spa treatments. The need for segmentation will also result from changes in the types of relationship between the spa enterprise and the spa patient. A modern health resort businesses model should be targeted towards the market dependency of B2C (Business-to-Customer) type, creating especially value for the customer, instead of the currently used approach of B2B (Business-to-Business) or B2A (Business-to-Administration) type relating to direct payers (insurers).

Nowadays, communication channels with a potential patient are mainly based on websites, advertising banners and leaflets, as well as having a presence on social media. Another channel used by managers is cooperation with travel agencies, which allows for communication especially with individuals and business patients. Channels of communication with the customer should give special consideration to the progress of electronic communication, regardless of the age group of the recipients. Nowadays, people over 60 very often skillfully use both social media and electronic communication tools. An important structural change is the increasingly common acquisition of treatments by travel agencies. However, it is important to standardize this type of channel in order to make the medical side of the treatment more precise. In many cases, it is also necessary to re-educate general practitioners to offer spa treatments in direct contact with the patient after the diagnosis.

Revenue streams and cost structure contain similar items, although they do not always have the same significance in terms of their impact on the health resort enterprise. The managers emphasize that the most expensive activities are related to accommodation in a sanatorium and a health resort hospital, implementation of a health resort treatment, and also to catering. The same result is observed in the case of revenue hierarchy. A different significance is attached to the activity of a health resort clinic, which generates higher costs than revenues. The key revenues of health resorts are primarily 
generated by the performance of contracts concluded with insurers (which includes: National Health Fund, The Social Insurance Institution, The Agricultural Social Insurance Fund, and the National Disabled Persons' Rehabilitation Fund), but also from commercial activities targeted at individual and group patients, entrepreneurs, and sports organizations.

The component of the model that has undergone the greatest changes is the proposal of values that the spa enterprise offers to its customers. From the spas perspective, the value position consists of the core element, which is health treatment that uses local natural healing raw materials, fulfilled by the healing properties of the local microclimate, accommodation and medical infrastructure. Nevertheless, to fully understand the value proposed to patients, their perspective has to be included in the business model. To determine this component of the business model, the results of quantitative research were used, which are presented in the next subsection.

The in-depth interviews also revealed the most frequently used business strategy in spa enterprises. The possibility of servicing tourists in the spa treatment facilities allowed us to adopt double standards for the guests. This result has two reasons:

- the profitability of commercial guests' stays (individual and business), which is much higher than that of contractual guests;

- the marginal impact of the contractual guest on the conditions of stay and its settlement (the direct payer is the insurer and not the direct beneficiary of the treatment).

As a result, the offer addressed to individual and business customers has not only a higher standard with higher prices of services, but also higher profitability for the facility. Therefore, managers try to optimize the structure of the stays. They reduce the contractual possibilities with the insurer to the level of the expected filling of the remaining sanatorium places with individual guests, who provide them with higher profits from the activity. These proportions may vary over the year depending on the seasonal fluctuation of commercial stays.

The observations allowed us to notice an increase in the popularity of treatment combined with recreation and an increase in the number of elderly people with a simultaneous downward trend in the level of financing of health resort treatment from the National Health Fund sources. These phenomena make it more and more often necessary to turn to self-financing spa patients or to companies sending their employees to regenerate their mental and physical strength. From this perspective, this will have an impact on the new price mechanisms that the spa enterprises will have to develop in order to increase their effectiveness. The pricing mechanisms applied in health resorts already provide for a different approach to individual and group customers, for whom the catalog price is adopted or dependent on the features of the offer (depending on the product properties, market segment, transaction volume). For contract customers, the price mechanism depends on the terms of the negotiations and, usually, the size of the transaction is also relevant.

\subsection{The Needs and Expectations Towards Value Proposition of Spa Visitors and Potential Clients}

As mentioned before, the perspective of spa clients and potential spa clients shapes the value proposal made by an enterprise. They verify if what is presented as a value really serves this purpose, or if they discern it in some other elements of the offer. In order to properly meet the expectations and needs of spa visitors, it is needed to identify and include them into the value proposition of a model; therefore, the second part of the study was designed to reach this purpose.

In the sample of 753 subjects, $73.4 \%$ were women and $26.6 \%$ were men; this reflects the structure of patients observed in many other studies carried out in spas [53]. A similar structure is observed in individual subgroups of the examined tourists TS (77.3\% women and $22.7 \%$ men) and potential tourists PT (67.5\% women and $32.5 \%$ men). Among those surveyed, only $1.4 \%$ of them visited foreign spas, and at the same time, $1.6 \%$ of respondents lived outside of Poland.

People visiting the spas were mostly under the care of a spa doctor $(79 \%)$. Only every fifth respondent stayed in the spa without medical care (21\%); $61.2 \%$ of spa guests came there with the 
insurer's referral, which means that these people had no direct influence on the choice of spa in which they will take the treatment. Every third respondent had an influence on such a choice (34.8\%), and 4.0\% of respondents admitted that the choice was made by someone else (usually a family member).

Visitors to spas usually came from large cities with populations $(33.7 \%)$ over 100,000, or medium-sized cities with 20-100 thousand residents (31.9\%). Only every sixth respondent $(18.9 \%)$ came from the village. The presented general structure of origin of respondents is not significantly different in groups ( $p$ ST vs. $P T>0.05$ ). Almost the same number $(2.4 \%)$ came to spas only for 1 day.

At the beginning of the research, the respondents were asked about attributes of a spa stay that make it a successful visit. Multiple options were available, as well as the possibility to add won remarks. The results are shown in Table 2.

Table 2. Attributes that make for a successful spa stay.

\begin{tabular}{cc}
\hline Attributes That Make for a Successful a Spa Stay & Point Out Percentage \\
\hline The quality of medical care and treatment & $65.5 \%$ \\
The quality of accommodation & $63.3 \%$ \\
A wide range of treatment & $40.8 \%$ \\
The quality of gastronomy & $26.8 \%$ \\
Beautiful views & $24.1 \%$ \\
Peace and quiet & $17.3 \%$ \\
A wide range of tourist attractions available & $12.9 \%$ \\
Cleanness of the park and its charm & $7.1 \%$ \\
The costs of treatments & $6.8 \%$ \\
The possibility to socialize with other visitors & $6.6 \%$ \\
A wide range of local culture attractions & $4.4 \%$ \\
Transportation (accessibility, parking lot) & $4.1 \%$ \\
The accommodation cost & $3.3 \%$ \\
Cleanness of the streets & $2.7 \%$ \\
Entertainment (cinema, dancing) & $2.5 \%$ \\
Safety of the location (low crime rate) & $1.1 \%$ \\
Mass events, concerts, carnivals & $0.0 \%$ \\
Other & $0.8 \%$ \\
\hline
\end{tabular}

Source: own research.

One can notice that the quality of medical care and treatment $(65.5 \%)$ and the quality of accommodation $(63,3)$ have been the most frequently selected answers, being the only ones pointed out by more than $60 \%$ of participants. The diversity in treatments offered was the third $(40.8 \%)$ most popular answer, outclassing attributes such as entertainment options $(2.5 \%)$ or access to cultural tourism attractions $(4.4 \%)$. It is interesting in juxtaposition with answers that regarded value propositions that would enrich a spa stay. Those answers are presented in Table 3, showing overall scores, as well as percentages in groups of spa visitors (TS) and potential clients (PT).

The expectations towards value proposition vary significantly between spa patients and potential tourists in most cases. Both groups are consistent in expecting improvements of accommodation standards, making it the most frequently named improvement overall (51\%). However, awaiting better quality of medical care occurs in the potential visitors group more frequently ( $9 \%$ difference) than in the actual patients group. Another major difference can be found in expectations towards visitor treatment. People who have not been to a spa before expect the facilities to improve in that aspect $(41.9 \%)$ significantly $(p<0.05)$ more frequently than actual patients $(27.8 \%)$. This might indicate that a large portion of respondents who have never been to a spa perceive those places as uncomfortable, with insufficient quality in service, not offering enough entertainment and not being addressed to younger people. Those two last observations come from relatively big differences in answers given in those two groups to the questions regarding the development of cultural activities (over $20 \%$ difference) and offering child care for the time of treatment (over $16 \%$ difference). 
Quantitative research has also shown what the most important values for spa patients are. The results are shown in Table 4.

Table 3. Value propositions that would enrich spa stays.

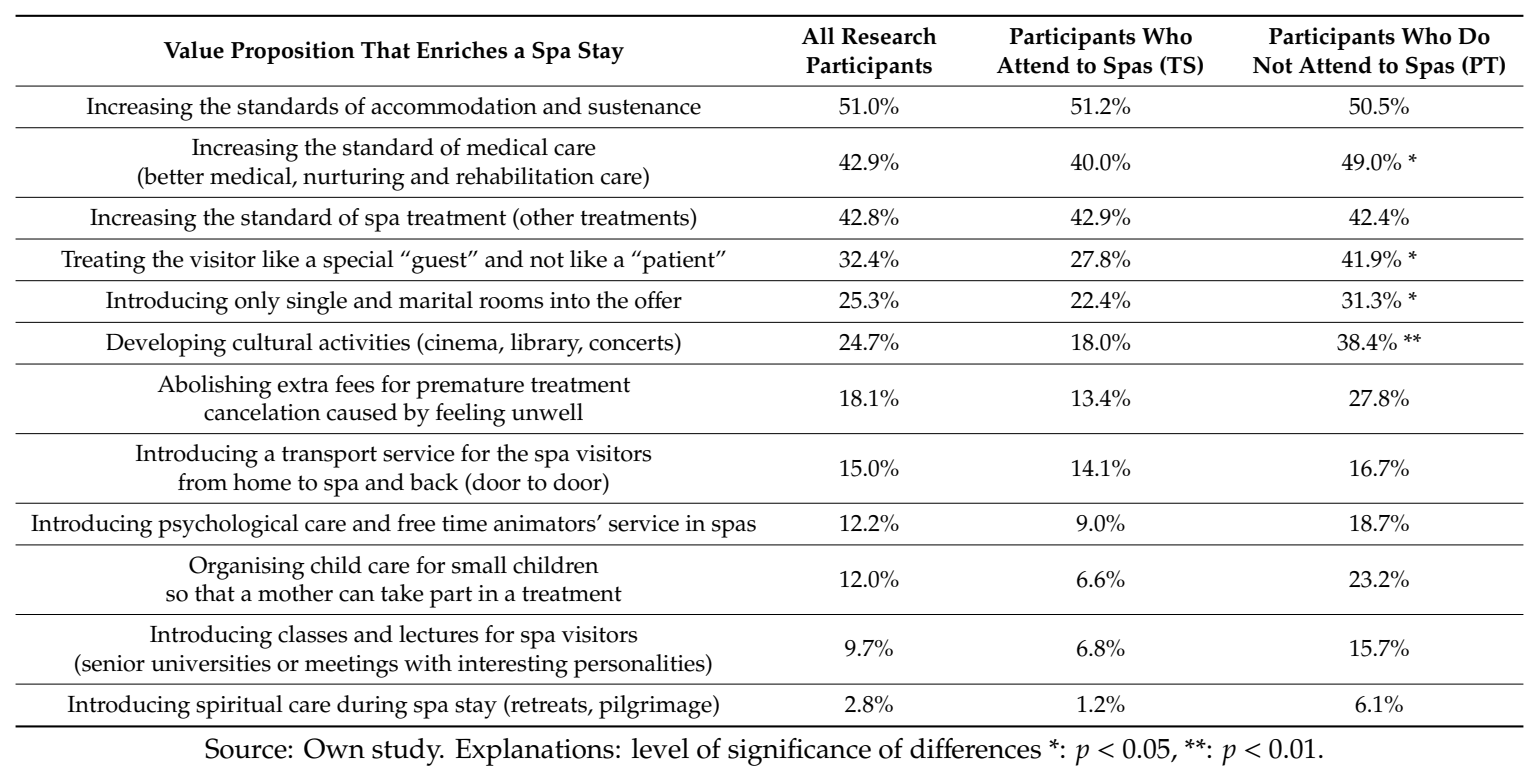

Table 4. The most important values for a visitor during a spa stay.

\begin{tabular}{cc}
\hline The Most Important Values for Visitor During a Spa Stay & Answer Percentage \\
\hline Sustaining or improving health conditions by applying natural healing resources (raw materials) & $66.0 \%$ \\
\hline Resting in a place where the climate has therapeutic properties & $38.7 \%$ \\
\hline $\begin{array}{c}\text { Achieving relaxing effects of treatment (better state of being, rest, beauty, } \\
\text { weight loss, condition and sport's performance improvement) }\end{array}$ & $29.8 \%$ \\
\hline Health, physical and emotional (mental/spiritual) safety provided by medical care. & $17.0 \%$ \\
\hline The opportunity to socialise and get entertained (chats, games, trips) & $15.9 \%$ \\
\hline The opportunity to participate in various forms of tourism & $8.6 \%$ \\
\hline Cultural and spiritual experiences, gained through attending concerts and religious ceremonies & $2.8 \%$ \\
\hline
\end{tabular}

Source: own research.

It is worth noticing that the main value for health resort customers is the effects of healing and recreation treatment. Those are the values that are obtained from natural resources, available only at the sight of a spa. Moreover, those values allow to diversify the spa enterprises' product from other wellness offers. The beneficial effects of relaxation services such as stress relief, sense of beauty, beauty improvement, weight loss, fitness, and sports performance are also important, but not unique for spas. A significant value is also the tourist's integration with other tourists (co-patients) with similar health, life, and social situations, or showing similar interests and ways of spending free time. An important value is the ability to break away from the everyday life.

\section{Discussion}

Activities in the conducted research related to the process of creating a business model dedicated to spa enterprises involved the analysis of business models, both in terms of reviewing definitions and typology, as well as the concept of creating and transforming business models. The structures of business models proposed in literature and their implementation in descriptive and analytical dimensions were also examined. Empirical research consisted of conducting in-depth interviews among managers of the largest spa enterprises in Poland. The actual knowledge of business models 
among managers of the studied companies is negligible and fragmentary, as it usually refers to their abstract understanding, but without text or graphic representation of the related architecture structures of the model or the proposed services. Only 5 managers among 17 surveyed spa establishments declared knowledge and use of the business model in running a spa activity. The spa enterprises in Poland use the business model very rarely and only to the extent limited to certain elements of their activity, and not always with the awareness of the wide range of possibilities of its application.

In the case of one of the elements in the business model - the proposal of value for the customer-it was necessary to perform additional research of a quantitative nature. Their aim was to learn about the expectations of spa patients and potential patients and to create a value proposition that would be attractive to customers and enable the identification of additional customer segments.

Quantitative research conducted on a representative sample of the respondents also revealed the needs of spa patients and potential patients towards the spa facilities. It is worth mentioning that the key values for the customer of a spa enterprise are the provided healing, leisure and recreational services. In this respect, health services, which are at the same time consistent with the objectives of the majority of spa stays undertaken by the patients, are the leading ones. Moreover, based on the quantitative data gained, one can assume that there is a gap in expectations of current spa visitors and potential clients. In order to attract them, newly proposed values in a spa business model could address those needs, offering not only health improvements, but entertainment and activities that can be enjoyed by age group. This, however, does not come without risks. Those highly expected by potential clients values diverge from the needs of current customers, and when implemented, could discourage them from further use. The only common thread for both groups was the core of spa stays, that is, using natural resources (raw materials and climate) to improve health conditions.

In the course of literature and empirical research, revealing significant differences between managers in the approach to the objectives of conducting spa business, as well as the way of formulating the health resort offer and strategy of conducting business in the financial sphere, it was noted that an individual approach to business modeling in health resort enterprises is necessary. Therefore, the presented initial model, concerning the presentation of the spa enterprise in its generalized form, requires additional presentation in the form of several key variants (Figure 2). 


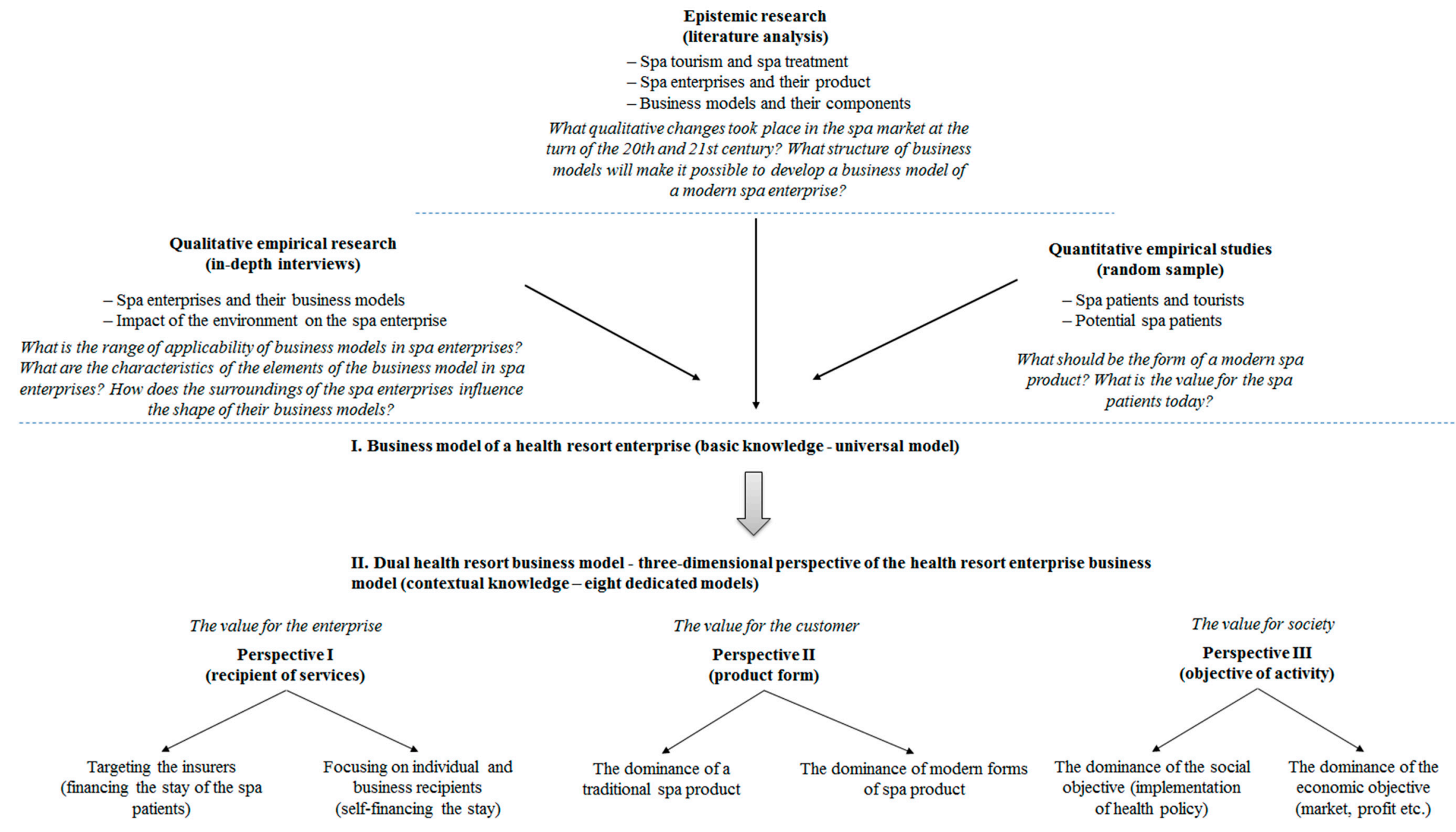

Figure 2. Implementation of the research process towards the development of a business model dedicated to health resort enterprises. Source: Own study. 
In the case of modern health resort activities, it seems justified to use two main criteria of division of the business strategy and business model, and thus two perspectives of conducting activities, i.e.,:

(a) Perspective I is oriented towards the creation of value for the enterprise, which uses the criterion of model division based on the type of recipient of services, with the two dominating groups of recipients:

- insurers (financing the stay of spa patients from insurance funds),

- individual and business recipients (self-financing the stay).

(b) Perspective II focuses on customer value creation, which uses the criterion of model division based on the type of health resort product in which dominates:

- traditional form of a spa product (spa treatment),

- a modern form of a spa product (mixed).

The dichotomous division of directions of activities in each of the criteria mentioned above indicates the dual nature of the business model. From the first perspective, the dual model assumes the adoption of a different cost structure in relation to the presented key customer groups.

In the case of contracts with insurers, it is assumed that costs will be minimized; the value will be built for the customer with low prices and mass availability of offered products and services (cost-driven). Whereas for other customers (individual and business), it suggests using a highly personalized offer of the spa, at the same time deriving from it a high income (value-driven).

From the second perspective, business models should clearly define a proposal of value for the customer, depending on whether they want to implement a traditional healing offer or a spa product is to be a mixed product, covering both traditional natural healing services and non-healing services (relaxation, recreation, cosmetic, sports).

However, it should be noted that the presented structure of the division of options for the necessary scenarios is still incomplete, as it lacks the purpose of tourist and healing activities. Health resorts, although they generally pursue both economic and social objectives, differ from one another in terms of the predominant objective of their business activity. Some focus their activities almost exclusively on achieving profit or acquiring new customers, while others try to achieve mainly social objectives, being satisfied with the income from the execution of contracts with the insurers. Therefore, it is proposed to modify the approach based on two criteria of division, introducing a third dimension of spa activities involving the domination of a specific objective.

Perspective III is therefore aimed at creating value for society, which uses the criterion of model division based on the dominant purpose of tourist and healing activity in the health resort, which may be first of all:

- implementation of the social objective (implementation of the health policy while limiting the load of the area with tourist traffic and eliminating overtourism),

- $\quad$ achieving primarily an economic objective (market, profit or other).

Perspective III is not exclusive, as is the case for perspectives I and II, as it can be applied simultaneously with the other two. Therefore, it is possible to integrate two perspectives at the same time (III and I and III and II). The existence of perspective III introduces changes in business models of the two previously discussed perspectives, because in some cases, e.g., domination of social objectives will require finding additional revenue streams, especially when the activity will be directed to the mixed form of a health resort product.

In the context of these three perspectives, the characteristics of the eight business model options have been summarized, depending on the used combination of perspectives and their variants. Their general perception is facilitated by the three-dimensional perspective of business models dedicated to health resort enterprises (Figure 3). 


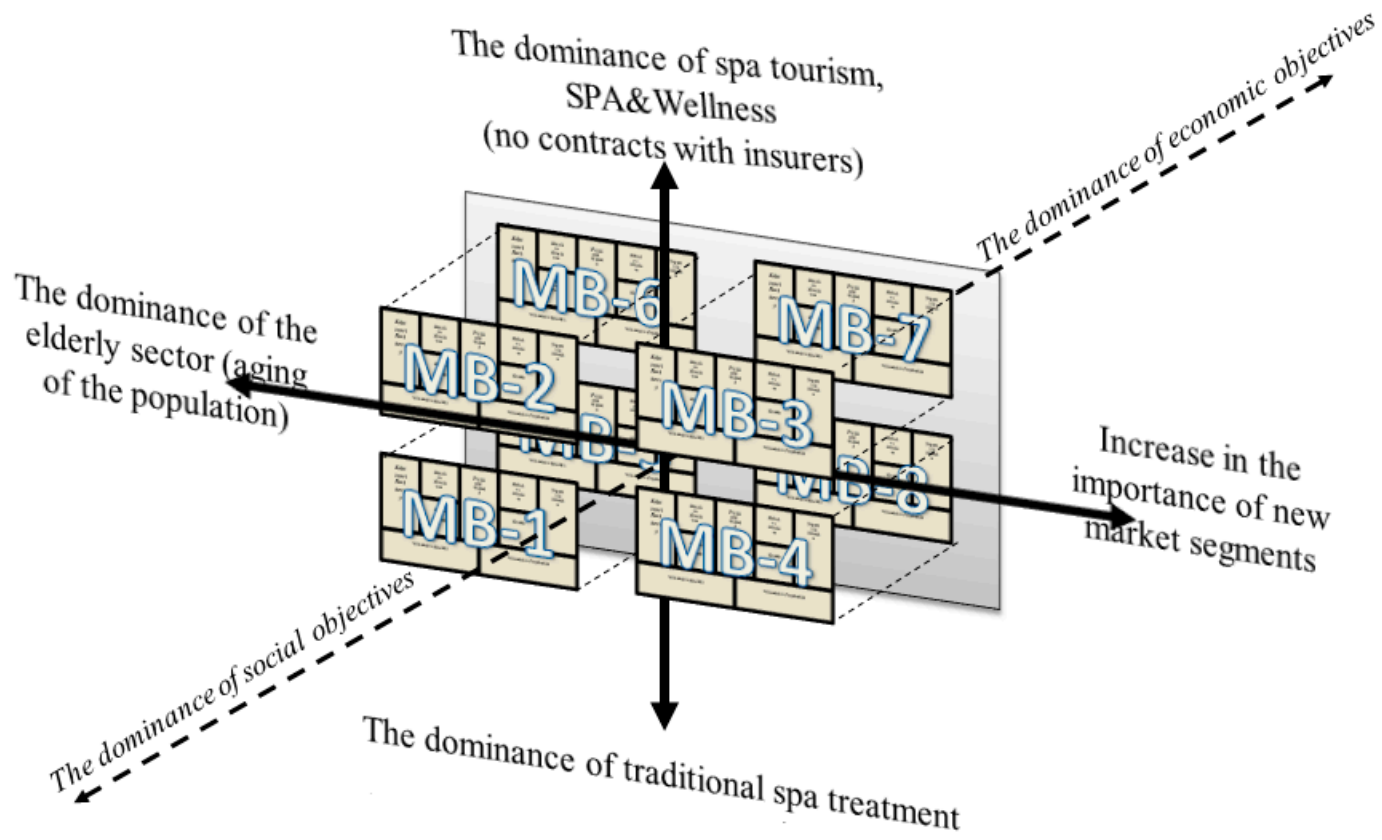

Figure 3. Three-dimensional scheme of a dual business model dedicated to health resort enterprises. Source: Own study.

\section{Conclusion}

In the summary of variants of the model dedicated to health resort enterprises presented in the paper, the possibility of using not only one variant at the same time, but at least two variants, was noticed. The criteria for their selection have also been defined. The observation of the studied spa facilities indicates that in general it will be determined by the desire to serve both extreme market segments or to achieve both objectives of tourist and healing activities. An important premise may also be a specific feature of a particular establishment, emphasizing its uniqueness, e.g., in terms of the uniqueness of the presence of raw materials at the disposal of the establishment (underground salt pits, thermal springs).

It should be noted that there are two limitations to the research. The first concerns the fact that research concerns the area of Polish health resorts and may not be representative of all health resorts in the world. It is therefore worth comparing research in other countries. The second limitation is the method of reaching respondents (spa tourists). It was assumed that in this group there is access to Internet communication, but not every spa tourist uses the Internet.

In the face of the phenomenon of overtourism, it is particularly important to choose the form of a model aimed at achieving both financial and social goals. Implementation of financial goals can only lead to a spa for excessive exploitation [11,54]. However, focusing solely on the implementation of social objectives is burdened with the risk of excessive tourist traffic. The business model of a spa company should take into account the sustainable development of business in the field of choosing the objectives of a spa activity. In the conducted research, the need to include in business models activities that protect spa areas against excessive pressure on tourism and the exploitation of natural resources was noticed. Unfortunately, it is currently only a voluntary gesture of only those managers who understand that excessive tourist load may cause a decline in the spa function.

Because this was the first attempt to specify business models and value proposals in spa tours, further research is needed and it could build upon findings from this paper. The presented case of Polish spas could be compared to business models used in other European countries or even on the global scale, on one hand in order to pick out the differences, but on the other hand to attempt modeling a generic business model of spa enterprises. It might also be beneficial to classify values proposed by other spas. Future studies could also be helpful to determine if introducing features that 
are perceived as expected value by potential customers are also welcome, neutral or unacceptable for current spa patients. Furthermore, the developed methodology and tools used during research can be used to study business models in other kinds of touristic activities, such as heritage tourism, hospitality industry, or even partially in other businesses basd on supplying services.

Author Contributions: A.R.S. developed the whole paper-the methodology, introduction and conclusions, research, as well prepared the final contents of the article and proofread and revised it. M.N. supplemented the article with additional methodological explanations and a review of the literature.

Funding: This research received funding by the National Science Center in Poland.

Acknowledgments: This paper was published as part of the research project 'A business model for health resort enterprises' No. 2017/25/B/HS4/00301, supervised and financed by the National Science Center in Poland and as part of statutory research ROZ 1: BK-231/ROZ1/2018 (13/010/BK_18/0029) at the Silesian University of Technology, Faculty of Organization and Management.

Conflicts of Interest: The authors declare no conflict of interest. The funders had no role in the design of the study; in the collection, analyses, or interpretation of data; in the writing of the manuscript, or in the decision to publish the results.

\section{References}

1. Szromek, A.R. Development of health tourism in Polish spas in the context of air pollution, an aging population and changes in business models. In Proceedings of the 18th International Multidisciplinary Scientific GeoConferences SGEM2018, Albena, Bulgaria, 30 June-9 July 2018; Volume 18, pp. 199-206.

2. Szromek, A.R. Changes in the management model of health care institutions in health resorts in the context of social and economic changes in the years 1989-2018. Health Prim. Care 2018, 2, 1-2. [CrossRef]

3. Malara, Z. Przedsiębiorstwo w Globalnej Gospodarce; Wyzwania współczesności, PWN: Warszawa, Poland, 2007; pp. 12-14.

4. Nogalski, B. Modele biznesu jako narzędzia reorientacji strategicznej przedsiębiorstw. Master Bus. Adm. $2009,17,3-14$.

5. Lucas, R.C.; Stankey, G.H. Role of Research in Applying the Limits of Acceptable Change System. In Proceedings of the Southern Recreation Research Conference, Myrtle Beach, SC, USA, 28 February-1 March 1985; pp. 1-15.

6. Aall, C.; Dodds, R.; Sælensminde, I.; Brendehaug, E. Introducing the concept of environmental policy integration into the discourse on sustainable tourism: A way to improve policy-making and implementation? J. Sustain. Tour. 2015, 23, 977-989. [CrossRef]

7. Butler, R.W. The concept of a tourist area cycle of evolution: Implications for management of resources. Can. Geogr. 1980, 24, 5-12. [CrossRef]

8. Szromek, A.R.; Kapczyński, A. Hypotheses concerning the development of Polish spas in the years 1949-2006. Tour. Manag. 2008, 29, 1035-1037.

9. Lindberg, K.; McCool, S.; Stankey, G. Rethinking Carrying Capactiy. Ann. Tour. Res. 2007, 24, 461-465. [CrossRef]

10. Kruczek, Z.; Kruczek, M.; Szromek, A.R. Possibilities of Using the Tourism Area Life Cycle Model to Understand and Provide Sustainable Solution for Tourism Development in the Antarctic Region. Sustainability 2018, 10, 89. [CrossRef]

11. Dodds, R.; Butler, R. (Eds.) OVERTOURISM. Issues, Realities and Solutions. De Gruyter Studies in Tourism; De Gruyter Oldenbourg: Berlin, Germany, 2019; Volume 1.

12. Szromek, A.R.; Romaniuk, P.; Hadzik, A. The privatization of spa companies in Poland-An evaluation of policy assumptions and implementation. Health Policy 2016, 120, 362-368. [CrossRef]

13. Szromek, A.R.; Herman, K. A Business Creation in Post-Industrial Tourism Objects: Case of the Industrial Monuments Route. Sustainability 2019, 11, 1451. [CrossRef]

14. Wirtz, B.; Pistoia, A.; Ullrich, S.; Gottel, V. Business Models: Origin, Development and Future Research Perspectives. Long Range Plan. 2016, 49, 36-54. [CrossRef]

15. Konczal, E. Models are for Managers, not Mathematicians. J. Syst. Manag. 1975, 26, 12-15.

16. Magretta, J. Why business models matter? Harv. Bus. Rev. 2002, 80, 86-92. [PubMed]

17. Teece, D. Business models and dynamic capabilities. Long Range Plan. 2018, 51, 40-49. [CrossRef] 
18. Battistella, C.; Toni, A.; Zan, G.; Pessot, E. Cultivating business model agility through focused capabilities: Amultiple case study. J. Bus. Res. 2017, 73, 65-82. [CrossRef]

19. Prendeville, S.; Bocken, N. Sustainable Business Models through Service Design. Procedia Manuf. 2017, 8, 292-299. [CrossRef]

20. Geissdoerfer, M.; Savaget, P.; Evans, S. The Cambridge Business Model Innovation Process. Procedia Manuf. 2017, 8, 262-269. [CrossRef]

21. Johnson, W.; Christensen, C.; Kagerman, H. Reinventing Your Business Model. Harv. Bus. Rev. 2008, 86, 57-68.

22. Falencikowski, T. Strategia a model biznesu-podobieństwa i różnice. Prace Naukowe Uniwersytetu Ekonomicznego we Wrocławiu 2012, 260, 80-93.

23. Rusu, B. The Impact of Innovations on the Business Model: Exploratory Analysis of a Small Travel Agency. Procedia-Soc. Behav. Sci. 2016, 221, 166-175. [CrossRef]

24. Wiśniewski, A. Konstrukcja Modeli biznesu. Acta Universitatis Nicolai Copernici Zarzadzanie 2017, 44, 75-85. [CrossRef]

25. Al-Debei, M.; El-Haddadeh, R.; Avison, D. Defining the Business Model in the New World of Digital Business. In Proceedings of the Fourteenth Americas Conference on Information Systems, Toronto, ON, Canada, 14-17 August 2008.

26. Iwasieczko, B. Modele biznesowe i ocena czynników ich efektywności. Prace Naukowe Uniwersytetu Ekonomicznego we Wroctawiu 2014, 343, 154-163. [CrossRef]

27. Souto, J. Business model innovation and business concept innovation as the context of incremental innovation and radical innovation. Tour. Manag. 2015, 51, 142-155. [CrossRef]

28. Bodenau, A. Innovative Value of Sustainable Tourism Practices. In Proceedings of the 22nd Nordic Symposium in Tourism and Hospitality Research, Bodø, Norway, 24-27 September 2013; pp. $23-25$.

29. Mantaguti, F.; Mingotto, E. Innovative business models within niche tourist markets: Shared identity, authenticity and flexible networks. The case of three Italian SMEs. J. Tour. Res. 2016, 6, 9-10.

30. Cranmer, E.; Jung, T.; Dieck, M.C.T. The Value of Augmented Reality from a Business Model Perspective. e-Review of Tourism Research. February 2017. Available online: https://ertr.tamu.edu/ (accessed on 9 December 2017).

31. Ciurea, C.; Filip, F.G. Validation of a Business Model for Cultural Heritage Institutions. Informatica Economică 2015, 19, 46-56. [CrossRef]

32. OECD. Tourism and the Creative Economy. In OECD Studies on Tourism; OECD Publishing: Paris, France, 2014; p. 25.

33. Prebensen, N.; Dahl, J. Value co-creation significance of tourist resources. Ann. Tour. Res. 2013, 42, $240-261$. [CrossRef]

34. Diaconu, M.; Dutu, A. Business model in the hospitality industry, from traditional to open innovation. Sci. Bull. Econ. Sci. 2014, 16, 3-10.

35. Knop, L.; Brzóska, J. Rola innowacji w tworzeniu wartości poprzez modele biznesu. Zeszyty Naukowe Organizacja i Zarządzanie/Politechnika Ślaska 2016, 99, 215-217.

36. Gordijn, J.; Akkermans, H. Business models for distributed generation in a liberalized market environment. Electr. Power Syst. Res. 2007, 77, 1178-1188. [CrossRef]

37. Chesbrough, H. Business Model Innovation: Opportunities and Barriers. Long Range Plan. 2010, 43, 354-363. [CrossRef]

38. Teece, D.J. Business Models, Business Strategy and Innovation. Long Range Plan. 2010, 43, 172-194. [CrossRef]

39. Page, S. Transport for Tourism. In A Companion to Tourism; Lew, A.A., Hall, C.M., Williams, A.M., Eds.; Black-well: Oxford, UK, 2004; pp. 146-158.

40. Żemła, M.; Szromek, A.R. Preference for domestic offer in tourism among students in central European countries. Eur. J. Tour. Hosp. Recreat. 2014, 5, 183-196.

41. Jansen-Verbeke, M.; Spee, R. A regional analysis of tourist flows within Europe. Tour. Manag. 1995, 16, 73-80. [CrossRef]

42. Cater, E. Ecotourism: Theory and practice. In A Companion to Tourism; Lew, A.A., Hall, C.M., Williams, A.M., Eds.; Black-well: Oxford, UK, 2004; pp. 484-497.

43. Wang, S.; Qu, H. A comparison study of Chinese domestic tourism: China vs. the USA. International. J. Contemp. Hosp. Manag. 2004, 16, 108-115. [CrossRef] 
44. Ragavan, N.A.; Subramonian, H.; Sharif, S.P. Tourists' perceptions of destination travel attributes: An application to International tourists to Kuala Lumpur. Procedia-Soc. Behav. Sci. 2014, 144, 403-411. [CrossRef]

45. Kozak, M. Comparative assessment of tourist satisfaction with destinations across two nationalities. Tour. Manag. 2001, 22, 391-401. [CrossRef]

46. Akama, J.S. Measuring tourist satisfaction with Kenya's wildlife safari: A case study of Tsavo West National Park. Tour. Manag. 2003, 24, 73-81. [CrossRef]

47. Ángeles Oviedo-García, M.; Vega-Vázquez, M.; Castellanos-Verdugo, M.; Orgaz-Agüera, F. Tourism in protected areas and the impact of services cape on tourist satisfaction, key in sustainability. Tour. Manag. 2019, 12, 74-83.

48. Hea, X.; Hua, D.; Swanson, S.R.; Su, L.; Chenc, X. Destination perceptions, relationship quality, and tourist environmentally responsible behavior. Tour. Manag. 2018, 28, 93-104. [CrossRef]

49. Osterwalder, A.; Pigneur, Y. Business Model Generation: A Handbook for Visionaries, Game Changers, and Challengers; John Wiley \& Sons: Hoboken, NJ, USA, 2010; p. 190.

50. Greenacre, M.; Hastie, T. The Geometric Interpretation of Correspondence Analysis. J. Am. Stat. Assoc. 1987, 82, 437-447. [CrossRef]

51. Kendall, M.G. Multivariete Analysis; Charles Griffin: London, UK, 1975; pp. 3-198.

52. Stanisz, A. (Ed.) Biostatystyka; Wyd. Uniwersytetu Jagiellońskiego: Kraków, Poland, 2005; pp. 109-409.

53. Dryglas, D.; Salamaga, M. Segmentation by push motives in health tourism destinations: A case study of Polish spa resorts. J. Destin. Mark. Manag. 2018, 9, 234-246. [CrossRef]

54. Szromek, A.R. Revitalization of Polish spas. In Tourism in the New Eastern Europe Global Challenges-Regional Answer; College of Tourism and Hospitality Management: Warszawa, Poland, 2008; pp. 115-118.

(C) 2019 by the authors. Licensee MDPI, Basel, Switzerland. This article is an open access article distributed under the terms and conditions of the Creative Commons Attribution (CC BY) license (http://creativecommons.org/licenses/by/4.0/). 